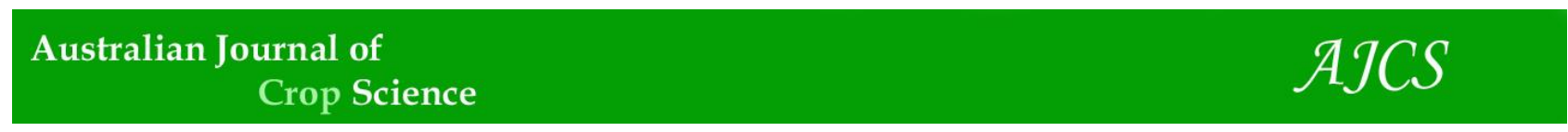

AJCS 15(07):1020-1028 (2021)

ISSN:1835-2707

doi: 10.21475/ajcs.21.15.07.p3030

\title{
Evaluation 16 elite sugarcane lines for ethanol yield and yield related traits under
} rainfed conditions

\author{
Darika Bunphan ${ }^{1 *}$, Ruchuon Wanna ${ }^{1}$, Goitseone Malambane ${ }^{2}$ \\ ${ }^{1}$ Department of Agricultural Technology, Faculty of Technology Mahasarakham University, Kantarawichai \\ District, Mahasarakham $\mathbf{4 4 1 5 0}$ Thailand \\ ${ }^{2}$ Department of Crop and Soil Sciences, Faculty of Agriculture, Botswana University of Agriculture and \\ Natural Resources, Gaborone, Botswana
}

*Corresponding author: darika.bu@msu.ac.th

\begin{abstract}
The world demand for clean renewable energy has seen a rise in use of sugarcane in production of bioenergy products like bioethanol which is produced from molasses and extracted juice of stalk. This then brings a competition between production for food and for bioenergy in the sugarcane industry. Therefore, this calls for breeders and producers to develop and produce high yielding sugarcane varieties to meet the demand. We undertook a study with the aim to screen the recently released elite lines for the ethanol yield and related traits. The study was conducted in two locations under rainfed conditions in Maha Sarakham, Thailand. The results showed that all the locations had no effect on the studied genotypes thus suggesting that they are stable over different locations. The mean values show that SG. KK07-478 and RT2004-085 showed better performance recording higher juice yield, juice weight, TSS, percent of ethanol and estimated ethanol yield in both locations. We found interaction between location and variety except in TSS and percent of ethanol, RT2004-085 showed the highest TSS, juice weight, SG, PE and EEY in combine both locations. A high correlation of EEY to juice yield $\left(0.967^{* * *}\right)$ and juice weight $\left(0.978^{* * *}\right)$ also percent ethanol was highly correlated with TSS (0.953**) this then suggest that to improve ethanol yield breeders should focus on improved the performance of juice yield, juice weight and the TSS. Because of the higher performance, KK07-478 and RT2004-085 should further be evaluated in several other locations before they are adopted by farmers.
\end{abstract}

Keywords: Polarization, CCS, brix value, sugar content, association traits.

Abbreviations: TSS_Total soluble solid; Pol_Polarization; CCS_commercial cane sugar; SG_specific gravity; OM_organic matter; EC_electrical conductivity; RCBD_randomized complete block design; PE_percent of ethanol; EEY_estimated ethanol yield.

\section{Introduction}

The effects of climate change caused by continued use of fossil fuels and the ever-fluctuating petroleum prices has driven researchers into finding alternative renewable energy sources. Several crops have been identified as suitable for bioenergy production and among these crops' sugarcane has shown to be the most promising in production of bioethanol, as most of the ethanol currently produced is derived from sugarcane juice (Waclawovsky et al., 2010; Santchurn et al., 2014). The global production of sugarcane has seen an upward trend over the years mostly driven by the demand of sugar and sugar byproducts (Rumánková and Smutka, 2012) and the increasing production of bioethanol and biofuel (Svatoš et al., 2013). These increases in demand for sugar and other industrial byproducts calls for increase in production of sugarcane but there are several factors that hamper the increase in sugarcane production. Climate change and environmental stress has been the major challenge to agriculture more especially the crop production (Zhao and Li, 2015) and just like any other agricultural enterprise, sugarcane is also vulnerable to these challenges more especially the changes in temperatures (Knox et al., 2010; Carvalho et al., 2015) and precipitation (Li and Wei, 2006; Li and Yang, 2014). In view of this demand in sugarcane as both food crop and bioenergy crop and the challenges the production faces, the breeders continuously strive to breed and release varieties that will be high yield in order to meet demand from the two important sectors in today life.

Sugarcane (Saccharum officinarum L.) is thought to have originated from the South Pacific in the New Guinea by crosses and back-crossing with the original type, $\mathrm{S}$. spontaneum, occurring wild from Africa, India and through the Pacific to New Guinea (Purseglove, 1974). It is one important industrial crop that has been exploited globally in sugar production and bioenergy feedstock as one alternative energy crop (McMillan, 1997). It is thus considered the most essential crop as its byproducts are used in almost every household the world over (Zulu et al., 2019) and has been suggested as the most important cash crop in some Asian countries (Sapkota et al., 2019; Karim et al., 2016). Sugarcane, on average, accounts for nearly $80 \%$ of global sugar production and with the top ten producing countries (India, Brazil, Thailand, China, the US, Mexico, Russia, Pakistan, France, Australia) accounting for nearly $70 \%$ of global output (International Sugar Organization, 2020). 
Thailand is on the top ten sugarcane producing countries in the world, thus making the crop to have high economic importance in the country. Sugarcane production in Thailand for the year 2018/2019 was recorded at $131.9 \mathrm{~m}$ t from the production area of $1.96 \mathrm{~m}$ ha. Even though Thailand is one of the top producing countries, some of the production areas still have challenges in obtaining good productivity per unit area. The Northeast of Thailand accounts for higher production area ( $0.85 \mathrm{~m}$ ha) but has lower production yield (45.88 $\mathrm{m} \mathrm{t}$ ) as compared to other part of Thailand which shows bad productivity. One of the major reasons for low productivity in this part of the country is mainly because most farmers produce under rainfed conditions. In addition, the low soil fertility in the area adds on to the factors that leads to low productivity. Therefore, specific varieties for sugarcane production for the Northeast Thailand are required. To counter these problems, it is important to invest in specific varieties that will do well in the poor soils and with minimal water. Recently, new sugarcane varieties have been developed by breeders specifically to address the problem of low productivity in the North eastern part of the country were rainfed production is highly practiced.

Bio-ethanol production from molasses were reported several previously studies (Lavarack 2003; Arshad et al., 2017; Alamri et al., 2015), but so far there has been a few studies (Giri et al. 2013; Bunphan et al., 2015) that focusses on evaluating ethanol yield and yield related traits from juice cane. It is every farmer wish to plant cultivars that will give them better returns for their money. With the plant breeders continuously releasing varieties, it is thus upon us researchers to evaluate this varieties in different environments to select the appropriate ones to recommend to farmers. Therefore, our current study aims at evaluating the estimated ethanol yield and related yield traits of sixteen (thirteen elite and three check) sugarcane varieties grown under rain-fed condition in Maha Sarakham province, Thailand.

\section{Results and discussion}

\section{Soil properties}

The result of soil analysis results (Table 1 ), shows that we could characterize planting locations as low fertility soil with slightly acidity (L1; sugarcane field); and very low fertility soil with low acidity (L2; upland paddy rice field). The soil $\mathrm{pH}$ recorded at $\mathrm{L} 1$ field show slightly acidity (low soil pH) at 6.20 as compared to $L 2$ field which recorded very low acidity with $\mathrm{pH}$ of 4.67. Organic matter (OM) recorded from both locations were very low (0.52 and $0.47 \%)$; similar to electrical conductivity (EC) of both locations were very low. Other soil analysis results show that Phosphorus $(P)$ at $L 1$ location was recorded at $48 \mathrm{ppm}$ which was about was more than 3 times higher when compared to L2 location which recorded 13 ppm. Results of other minerals like potassium (K), calcium (Ca) and magnesium ( $\mathrm{Mg}$ ) of both locations were very low; however, $\mathrm{K}, \mathrm{Ca}$ and $\mathrm{Mg}$ content in $\mathrm{L} 1$ location was higher than in $\mathrm{L} 2$ location (Table 1 ). These results show that both areas were suitable for planting sugarcane as they were within the recommended rates.

The results of the soil analysis came with a recommendation of lime application at a rate of $100 \mathrm{~kg} \mathrm{ha}^{1-}$ was proposed, but in this study the application of lime was not done. Even though previous studies have shown the optimum $\mathrm{pH}$ for sugarcane production to be around $\mathrm{pH} 7$ (McEnroe and Coulter, 1964), is has also been shown that the acidic soils do not affect yield that much and it tolerates $\mathrm{pH}$ ranging from 5-
8.5 (Srivastava and Rai, 2012). Although, the low soil pH did not have any effect on the juice quality parameters such as the TSS and PE, it did affect the growth and yield of the crops (data not shown), as yield from both experimental fields were lower as compared to potential sugarcane yield. This low cane yield was then thought to have affected the ethanol yield as it was previously found that cane yield has positive correlated to ethanol yield in sweet sorghum (Bunphan et al., 2014).

\section{Meteorological data}

An aggregate rainfall recorded during the planting period of this study was $1694.8 \mathrm{~mm}$. The water requirement for sugarcane production has been estimated to range from 1500-2500 evenly distributed over the growing season (Bella et al., 2009; Choudhary et al., 2013; Riajaya, 2020). The recorded aggregate rainfall for this current study thus falls around the minimum rainfall needed for minimal sugarcane growth and development. The daily temperature ranged between $24.1-30.6{ }^{\circ} \mathrm{C}$ with average temperature calculated at $27.8{ }^{\circ} \mathrm{C}$ and relative humidity $(\mathrm{RH})$ recorded at $73.1 \%$ (data not shown). The temperatures ranges experienced during the research period were with the recommended ranges of growth and development of sugarcane as it was between $20^{\circ} \mathrm{C}$ and $35^{\circ} \mathrm{C}$ (Mohsen et al., 1998; Bonnet et al., 2006)

\section{Genotype by environment interaction}

The results obtained from the ethanol yield related traits during growth and development of the sugarcane in both fields were subjected to Analysis of variance (ANOVA) and is presented in Table 2. The location ( $L$ ) effect on performances of the 16 sugarcane varieties showed that the location had no significant effect on the growth and development of the sugarcane cultivars in the two locations, our results were in contrast to various other studies which has shown that location had an effect on performance of genotypes (Rea and Vieira, 2002; Khan et al., 2015) and Mattos et al., (2013) had contrasting results showing location having a large percent influence on yield traits. A different result was observed by Ftwi et al., (2018) who observed both locations were not significance for some traits and significance for other traits of sugarcane when grown in various locations. This could suggest that the genotypes used in this study had a stable performance over the two locations. The genotype (G) effect showed to have had influence as the means of all agronomic traits among the sixteen varieties showed high significance differences, similarly Momotarz et al. (2020) and Guilly et al. (2017) found out that the differences attributed to genotypes was higher than the one attributed to the locations. A high $G$ $x \mathrm{~L}$ interaction in all traits except TSS and PE was observed in this study, a higher interaction was also observed by (Jamooza et al., 2019;) when evaluating several cultivars of sugarcane under different environments and in contrast Rodríguez et al. (2010) and Kumar et al. (2018) found out that the interaction accounted for a lesser percentage in difference in yield traits.

\section{Combined analysis of two locations for the ethanol yield and yield related traits}

Cane yield in our study showed no significant difference between the 16 varieties over the two locations of study (data not shown). A Similarly study by Khumla et al. (2012) on cane yield also showed no significant difference between the varieties studied. In that study the cane yield, TSS and pol were slightly higher than in our study probably on the check varieties, something that might be attributed to the 
difference in environmental conditions. However, fiber and purity in our present study recorded higher values as compared to the previous study in those cultivars.

Further, an analysis on the ethanol yield traits that were studied in our research (juice yield, juice weight, fiber, pol, purity, PE, total soluble solid and EEY) were subjected to statistical analysis (Table 3). The EEY in our research was calculated as per Somani and Taylor (2003) using the other yield traits like TSS, SG and juice yield for calculation as it has proved to be more efficient and reliable for calculating ethanol yield (Bunphan et al., 2015).

The results showed that KKU07-478 recorded the highest average of both juice yield and juice weight (42710.0 I/ha and $45.05 \mathrm{t} / \mathrm{ha}$, respectively) and it also had higher fiber (16.24\%), however, this cultivar recorded a lower pol and PE (15.42 and $11.57 \%$ respectively). Whereas,

RT2004-085 recorded the highest values on several traits, like, juice yield (39230.0 l/ha), juice weight (44.86 t/ha), moreover this cultivar recorded the highest fiber, pol and PE (17.04\%, 16.67 and $12.60 \%$ respectively), but it recorded a lower purity (86.24\%).

Something to be noted, is that some cultivar had outstanding performances in few traits i.e. cv. KKU06-501 and NSUT08-223-13 had higher fiber ( 16.15 and $16.60 \%$ respectively), pol ( 16.52 and $16.62 \%$ respectively) and purity ( 87.76 and $89.45 \%$ respectively), while cv. TBy28-0348 showed higher pol (16.62\%) and purity (88.54\%), whereas cv. 91-2-527 showed higher juice weight but having a lower juice yield (Table 3). The check varieties KPS01-12 and LK92-11 had also recorded higher purity on cane juice at $(88.69$ and $87.79 \%$ respectively).

The total soluble solids analysis recorded an average ranging between 18.23 and 22.15o brix, where cV. RT2004-085 had the highest TSS at 22.15을 brix. Several other cultivars (KK07478, KK06-501, NSUT08-22-3-13 and KPS01-12) recorded TSS of more than 20 brix (Fig.1). Quantification of the estimated ethanol yield (EEY) gave values that ranged from 1846.06 to $5062.19 \mathrm{l} / \mathrm{ha}$ on the studied cultivars. Similar to TSS, cV. RT2004-085 had the highest EEY of 5062.19 l/ha, the two other cultivars that had higher EEY were KK07-478 and 91-2527 that recorded EEY of 4998.44 and 4648.19 I/ha respectively (Fig. 2).

\section{Analysis per location}

\section{Sugarcane field (L1) for the ethanol yield and yield related traits}

Analysis of results showed that all studied traits had significant different except for the specific gravity (SG) in this study location. The SG is a very important trait for determining the EEY. The SG of the cane juice was also determined and the results shows that it had no significant difference among the cultivars studied. The mean values recorded for the SG ranged from 1.048 to 1.079 for all the 16 cultivars.

In this location the cv. KK07-478 recorded the highest values on several ethanol yield related traits i.e. juice yield and juice weight was recorded at $55496.9 \mathrm{l} / \mathrm{ha}$ and $58.9 \mathrm{t} / \mathrm{ha}$ respectively, it also had the highest PE at $12.08 \%$. However, this cultivar recorded lower values for some traits i.e. pol and fiber recorded at 17.23 and $14.27 \%$ respectively. One other cultivar that recorded high juice yield is the cv. 91-2527 which had $45676.3 \mathrm{l} / \mathrm{ha}$. In this location, higher values of Pol were recorded under cv. TBy28-0348 at 19.51 while PE was recorded at $11.95 \%$ for the same cultivar. Two more cultivars (KK06-501 and RT2004-085) had promising values of pol and $\mathrm{PE}$, whereas cv. NSUT08-22-3-13 also recorded promising values of Pol for this location (Table 4).

The TSS in this location ranged between 18.22 to 22.44 o brix, and cV. KK07-478 had the highest TSS at $22.44 \%$ followed by CV. RT2004-085, TBy28-0348, KK06-501 and KPS01-12 at 22.15, 22.03, 21.70 and 21.18 o brix respectively (Fig.3). The results recorded for EEY showed that KK07-478 had the highest EEY at $6684.38 \mathrm{l} / \mathrm{ha}$, this was not surprising as this cultivar had recorded high values on traits related to $E E Y$, the other two cultivars which recorded good values for EEY were cv. 91-2-527, CSB06-4-162 and KK3 with values of 4251.88 I/ha, 3703.75 and $3635.28 \mathrm{I} /$ ha respectively (Fig.4).

\section{Upland paddy rice field (L2) for the ethanol yield and yield related traits}

Similar to the first location, all ethanol yield related traits were analyzed and found to be significantly different except SG. The SG ranged between 1.024 to 1.173 and RT2004-085 had the highest SG. Among the other cultivars, cv. RT2004085 recorded outstanding results for most of the traits, as it had the highest juice yield (57647.5 I/ha), juice weight (67.6 t/ha), fiber (19.61\%), pol (14.72) and PE (13.26\%). Results for other cultivars consistent as they recorded high values for other traits and lower values for other traits like the cv. 91-2527 which had higher juice yield (45433.8 I/ha) and juice weight ( $48.8 \mathrm{t} / \mathrm{ha}$ ) but also recorded the lower fiber, pol and $\mathrm{PE}$ when compared among other cultivars. Also, the cv. NSUT08-22-3-13, CSB06-4-162 and KPS01-12 recorded the highest fiber and pol however while other traits i.e. juice yield, juice weight and percent of ethanol were lower (Table 5).

The TSS of sixteen varieties ranged between 18.32 to 22.15 ㅇ brix, cv. RT2004-085 also had the highest TSS (22.15 brix), whereas several cultivars recorded moderately higher TSS such as CSB06-4-162, NSUT08-22-3-13, KK06-501, KK3 and KK07-478 (Fig. 5). Cultivar RT2004-085 also recorded the highest value for EEY at $7633.13 \mathrm{l} / \mathrm{ha}$, followed by $\mathrm{cv}$. 91-2527 and CV. MPT02-458 at 5044.38 and $4083.75 \mathrm{l} / \mathrm{ha}$, respectively (Fig. 6).

\section{The correlation analysis among the traits related to ethanol a yield in sugarcane}

Correlation analysis of recorded traits was performed it showed that EEY had highly positive correlation to juice yield $\left(r=0.967^{* *}\right)$ and juice weight $\left(r=0.978^{* * *}\right)$ (Fig. 7A and B). The other high positive correlation was observed between juice weight and juice yield at $r=0.986^{* * *}$ (Fig. 7J). Moreover, we found $\mathrm{PE}$ to have high to moderate positive relationship with several traits, like; PE to TSS $\left(r=0.975^{* * *}\right)$, PE to pol $\left(r=0.883^{* * *}\right)$, PE to fiber $\left(r=0.712^{* * *}\right)$ and PE to SG $\left(r=0.664^{* * *}\right)$ (Fig. $7 \mathrm{C}$ to $7 \mathrm{~F}$ respectively). Fiber was moderately associated to TSS (Fig 7G) and to Pol (Fig 7I) and moreover TSS has highly correlated to pol was also found in recent study ( $\mathrm{r}=0.904^{* * *}$ ) (Fig. $\left.7 \mathrm{H}\right)$. Moreover, in the current study we found a moderate positive correlation between purity and fiber at $0.523^{*}$ and purity had moderate association to pol at $0.731^{* *}$ (data not shown). Several other studies (Péné and Béhou, 2020) have shown that the most relevant traits were related to the juice yield. Previous studies have also studied correlations between yield and yield 
Table 1. Soil properties at Sugar cane field (L1) and upland paddy rice field (L2).

\begin{tabular}{|c|c|c|c|c|c|c|c|}
\hline Location & $\mathrm{pH}$ & $\begin{array}{l}\text { OM } \\
(\%)\end{array}$ & $\begin{array}{c}E C \\
(\mathrm{dS} / \mathrm{m})\end{array}$ & $\begin{array}{c}\mathrm{P} \\
(\mathrm{ppm})\end{array}$ & $\begin{array}{c}\mathrm{K} \\
(\mathrm{ppm})\end{array}$ & $\begin{array}{c}\text { Ca } \\
(\mathrm{ppm})\end{array}$ & $\begin{array}{c}\mathrm{Mg} \\
(\mathrm{ppm})\end{array}$ \\
\hline Sugarcane field (L1) & 6.20 & $\begin{array}{c}0.52 \\
\text { (low) }\end{array}$ & 0.022 & 48 & 42 & 238 & 42 \\
\hline $\begin{array}{l}\text { Upland paddy rice } \\
\text { filed (L2) }\end{array}$ & 4.67 & $\begin{array}{c}0.47 \\
\text { (very low) }\end{array}$ & 0.019 & 13 & 32 & 108 & 24 \\
\hline
\end{tabular}

Table 2. Analysis of variance results for Juice and juice yield related traits of sixteen sugarcane varieties at two study locations.

\begin{tabular}{|l|c|c|c|c|c|c|c|c|}
\hline Factors & df & $\begin{array}{c}\text { Juice } \\
\text { yield }\end{array}$ & $\begin{array}{c}\text { Juice } \\
\text { weight }\end{array}$ & $\begin{array}{c}\text { Total soluble } \\
\text { solid (brix) }\end{array}$ & Fiber & Pol & $\begin{array}{c}\text { Purity } \\
\text { Percent } \\
\text { of ethanol }\end{array}$ \\
\hline Location (L) & 1 & ns & ns & ns & ns & ns & ns & ns \\
\hline Variety (V) & 15 & $* *$ & $* *$ & $* *$ & $* *$ & $* *$ & $* *$ & $* *$ \\
\hline L $\times$ VV & 15 & $* *$ & $* *$ & ns & $* *$ & $*$ & $*$ & ns \\
\hline
\end{tabular}

ns= non-significant; $*$ and $* *=$ significant at $\alpha=0.05$ and 0.01

Table 3. combined means of Juice yield and related traits of 16 sugarcane varieties of the two study locations.

\begin{tabular}{|c|c|c|c|c|c|c|}
\hline Variety & $\begin{array}{l}\text { Juice yield } \\
\text { (I/ha) }\end{array}$ & $\begin{array}{c}\text { Juice } \\
\text { weight (ton/ha) }\end{array}$ & $\begin{array}{l}\text { Fiber } \\
(\%)\end{array}$ & $\begin{array}{l}\text { Pol } \\
\text { (\%) }\end{array}$ & $\begin{array}{l}\text { Purity } \\
\text { (\%) }\end{array}$ & $\begin{array}{l}\text { Percent } \\
\text { of ethanol }\end{array}$ \\
\hline КК06-501 & 20884.4fg & $22.37 \mathrm{gf}$ & $16.15 \mathrm{abc}$ & $16.52 a$ & $87.76 a b c$ & 11.73b \\
\hline KK07-478 & $42710.0 a$ & $45.05 a$ & $16.24 a b c$ & $15.42 c$ & $84.95 \mathrm{def}$ & $11.57 \mathrm{bc}$ \\
\hline NSUT08-22-3-13 & $16305.0 \mathrm{~g}$ & $17.30 \mathrm{~h}$ & $16.60 \mathrm{ab}$ & $16.62 a$ & $89.45 a$ & $11.43 \mathrm{bc}$ \\
\hline RT2004-085 & $39230.0 a b$ & $44.86 a$ & $17.04 a$ & $16.67 a$ & $86.24 c d e$ & $12.60 a$ \\
\hline CSB06-2-15 & $18723.1 \mathrm{fg}$ & $19.80 \mathrm{gh}$ & $14.86 \mathrm{def}$ & $13.88 \mathrm{de}$ & 84.07efg & 10.04ef \\
\hline CSB06-2-21 & $34626.9 b c$ & $36.73 b c$ & 16.09abc & $13.45 \mathrm{de}$ & $84.51 \mathrm{~d}-\mathrm{g}$ & $10.06 \mathrm{ef}$ \\
\hline CSB06-4-162 & $29391.9 d$ & $31.75 \mathrm{~cd}$ & $15.82 \mathrm{bcd}$ & 15.93abc & $87.34 a b c$ & $11.28 \mathrm{bc}$ \\
\hline CSB06-5-20 & 26430.0de & 27.77def & $15.26 c-f$ & $13.49 \mathrm{de}$ & $87.90 a b c$ & $9.51 f$ \\
\hline TBy27-1385 & $18386.3 \mathrm{fg}$ & 19.63gh & 14.30ef & $13.30 \mathrm{e}$ & $83.49 \mathrm{fg}$ & $10.21 \mathrm{def}$ \\
\hline TBy28-0348 & $21173.1 \mathrm{fg}$ & $22.57 f g h$ & $15.49 b c d$ & $16.72 a$ & $88.54 a b$ & $11.55 b c$ \\
\hline MPT02-458 & $27480.6 d$ & $29.26 \mathrm{de}$ & $15.77 \mathrm{bcd}$ & 16.23abc & $88.56 a b$ & $11.26 \mathrm{bc}$ \\
\hline MPT03-166 & $30683.1 \mathrm{~cd}$ & $31.34 \mathrm{~cd}$ & $14.13 f$ & 14.13de & $82.39 \mathrm{~g}$ & $9.92 f$ \\
\hline $91-2-527$ & $42198.1 \mathrm{~cd}$ & 40.10ab & 15.44cde & $14.35 d$ & $83.38 f g$ & $11.00 \mathrm{bcd}$ \\
\hline KK3 (check) & $34551.3 b c$ & $36.03 b c$ & $16.36 \mathrm{abc}$ & $15.46 \mathrm{bc}$ & $86.34 \mathrm{bcd}$ & $10.78 \mathrm{cde}$ \\
\hline LK92-11 (check) & $27477.5 d$ & $29.82 d$ & $15.58 \mathrm{bcd}$ & $15.80 \mathrm{abc}$ & 87.79abc & $11.23 b c$ \\
\hline KPS01-12 (check) & 22313.1ef & 23.62efg & $15.74 b c d$ & 16.49ab & $88.69 a$ & $11.33 \mathrm{bc}$ \\
\hline F-test & $* *$ & $* *$ & $* *$ & $* *$ & $* *$ & $* *$ \\
\hline$C V\left(L^{*} R\right)$ & 29.37 & 26.4 & 62.16 & 56.67 & 1.90 & 4.34 \\
\hline$C V\left(L^{*} R^{*} T\right)$ & 15.42 & 16.5 & 6.37 & 5.89 & 2.23 & 6.56 \\
\hline
\end{tabular}

** = significant at $\alpha=0.01$

Table 4. Juice yield and related traits of sugarcane grown under rain-fed condition in location 1 (L1)

\begin{tabular}{|c|c|c|c|c|c|c|c|}
\hline Variety & $\begin{array}{l}\text { Juice yield } \\
\text { (I/ha) }\end{array}$ & $\begin{array}{l}\text { Juice weight } \\
\text { (t/ha) }\end{array}$ & SG & Fiber (\%) & Pol & Purity (\%) & $\begin{array}{l}\text { Percent } \\
\text { of ethanol }\end{array}$ \\
\hline KK06-501 & 23281.9fgh & 24.5def & 1.058 & 13.50b-h & $18.92 a b$ & $87.20 a b c$ & $11.68 \mathrm{ab}$ \\
\hline KK07-478 & $55496.9 a$ & $58.9 a$ & 1.055 & $14.27 \mathrm{bcd}$ & $17.23 c-f$ & $83.12 \mathrm{e}-\mathrm{h}$ & $12.08 a$ \\
\hline NSUT08-22-3-13 & $24438.8 \mathrm{e}-\mathrm{h}$ & 25.9def & 1.062 & $13.63 \mathrm{~b}-\mathrm{g}$ & $18.50 \mathrm{abc}$ & $88.78 a$ & 11.17a-d \\
\hline RT2004-085 & 20991.9fgh & 22.1ef & 1.057 & $14.47 b c$ & $18.62 \mathrm{abc}$ & 84.08efg & $11.94 a$ \\
\hline CSB06-2-15 & $28516.9 c-f$ & $30.2 b-e$ & 1.057 & 12.20gh & $14.97 \mathrm{~h}$ & $82.15 \mathrm{fgh}$ & $9.49 \mathrm{e}$ \\
\hline CSB06-2-21 & $32820.6 \mathrm{cde}$ & $34.7 \mathrm{bc}$ & 1.058 & $16.33 a$ & $15.85 \mathrm{fgh}$ & $83.06 \mathrm{e}-\mathrm{h}$ & $10.03 \mathrm{cde}$ \\
\hline CSB06-4-162 & $34548.1 c$ & $37.3 b$ & 1.079 & 12.13gh & 16.79efg & $84.83 c-f$ & 10.70b-e \\
\hline CSB06-5-20 & 21666.3fgh & 22.7ef & 1.051 & $14.87 a b$ & $15.66 \mathrm{gh}$ & $85.48 \mathrm{~b}-\mathrm{e}$ & $9.50 \mathrm{e}$ \\
\hline TBy27-1385 & $17783.1 \mathrm{~h}$ & $18.8 f$ & 1.059 & $13.07 c-h$ & 15.54gh & $80.87 \mathrm{~h}$ & 10.13 cde \\
\hline TBy28-0348 & $25048.1 d-h$ & 26.7def & 1.065 & $12.63 \mathrm{e}-\mathrm{h}$ & $19.51 a$ & $88.60 a$ & $11.95 a$ \\
\hline MPT02-458 & $18570.6 \mathrm{gh}$ & $20.0 f$ & 1.075 & $12.87 d-h$ & $18.31 a-d$ & $87.96 a b$ & $11.30 \mathrm{abc}$ \\
\hline MPT03-166 & $26907.5 \mathrm{c}-\mathrm{g}$ & $28.2 \mathrm{cde}$ & 1.048 & $12.00 \mathrm{~h}$ & $16.26 f g h$ & 83.86efg & $10.13 \mathrm{cde}$ \\
\hline $91-2-527$ & $45676.3 b$ & $31.4 \mathrm{bcd}$ & 1.060 & $14.10 \mathrm{~b}-\mathrm{e}$ & 16.79efg & $82.04 \mathrm{gh}$ & $10.92 a-d$ \\
\hline KK3 (check) & $33336.9 \mathrm{~cd}$ & $35.4 b c$ & 1.063 & $14.03 b-f$ & $16.92 \mathrm{~d}-\mathrm{g}$ & $84.44 d-g$ & $10.68 b-e$ \\
\hline LK92-11 (check) & $27656.3 c-f$ & $29.3 b-e$ & 1.063 & $12.87 d-h$ & $17.77 \mathrm{~b}-\mathrm{e}$ & $87.02 a-d$ & $10.91 a-d$ \\
\hline KPS01-12 (check) & 25333.1d-h & 26.6def & 1.053 & $12.47 \mathrm{fgh}$ & $18.35 a-d$ & $88.03 a b$ & 11.30abc \\
\hline F-test & $* *$ & $* *$ & ns & $* *$ & $* *$ & $*$ & $* *$ \\
\hline CV (\%) & 17.77 & 16.32 & 1.02 & 7.01 & 5.11 & 1.92 & 6.67 \\
\hline
\end{tabular}

$\mathrm{Ns}, *$ and ${ }^{* *}=$ non-significant, significant at $\alpha$ and 0.05 and 0.01 respectively 


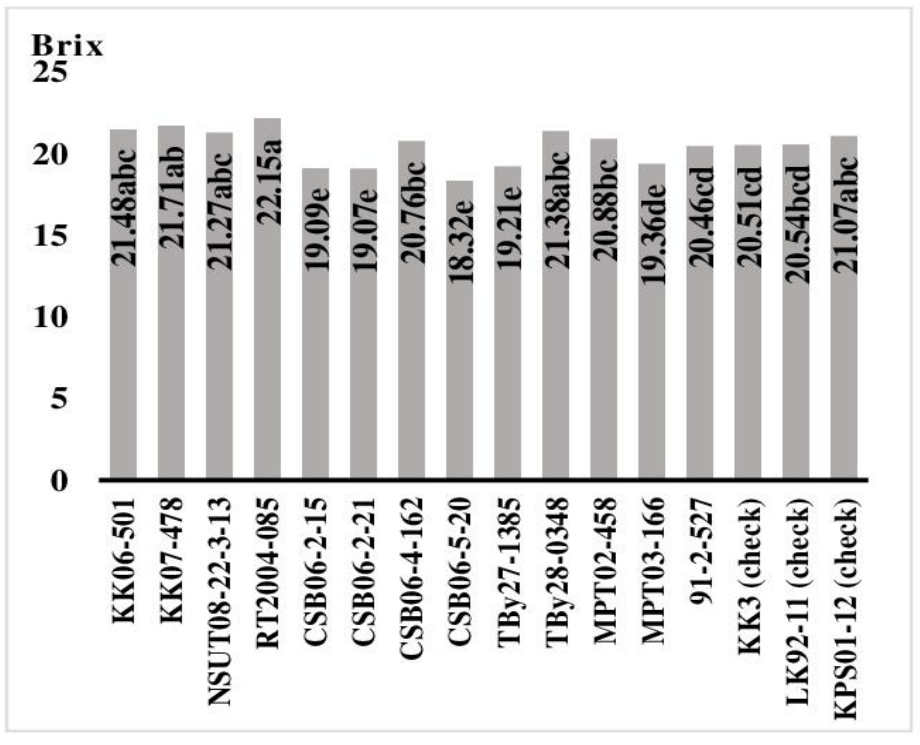

Fig.1 Means of TSS of 16 sugarcane varieties at two study locations

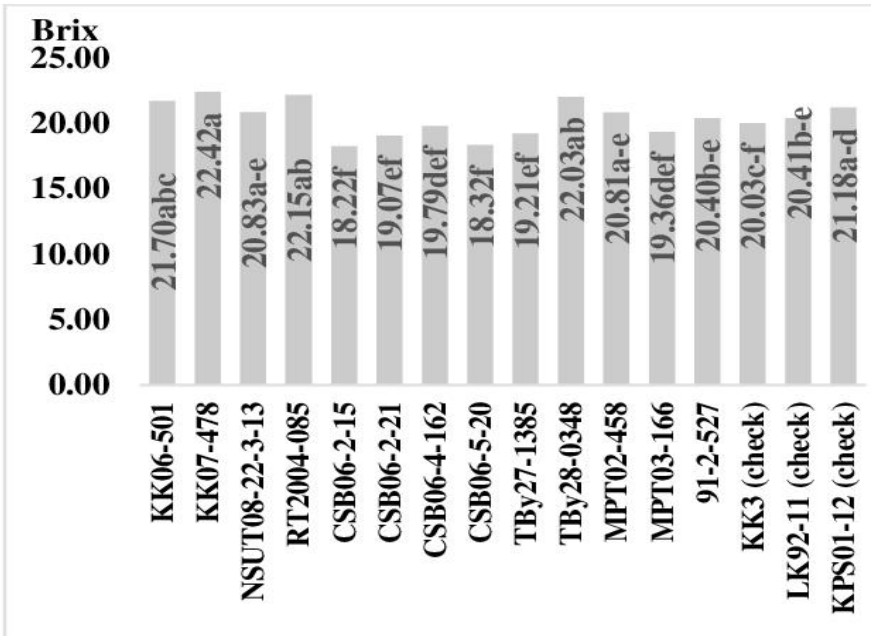

Fig.3 Means of TSS value of 16 sugarcane varieties grown at location $1(\mathrm{~L} 1)$

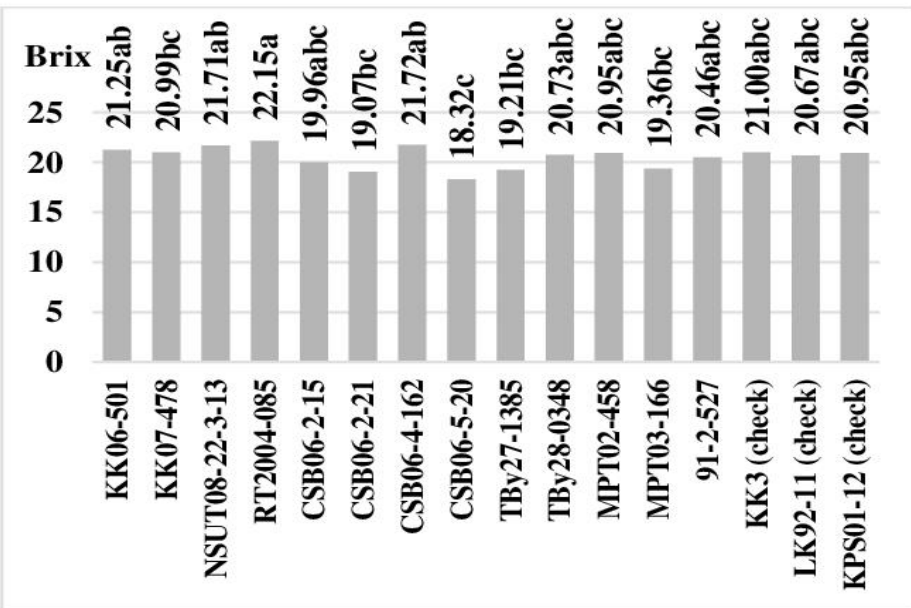

Fig. 5 Means of TSS value of 16 sugarcane varieties grown at location 2 (L2)

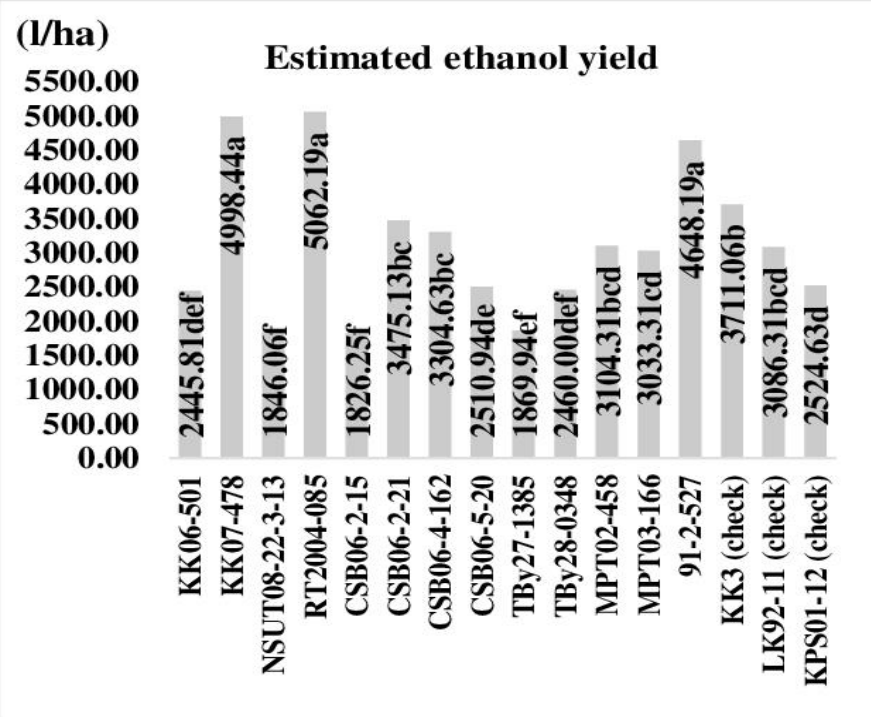

Fig.2 Means of estimated ethanol yield of 16 sugarcane vaarieties at two study location

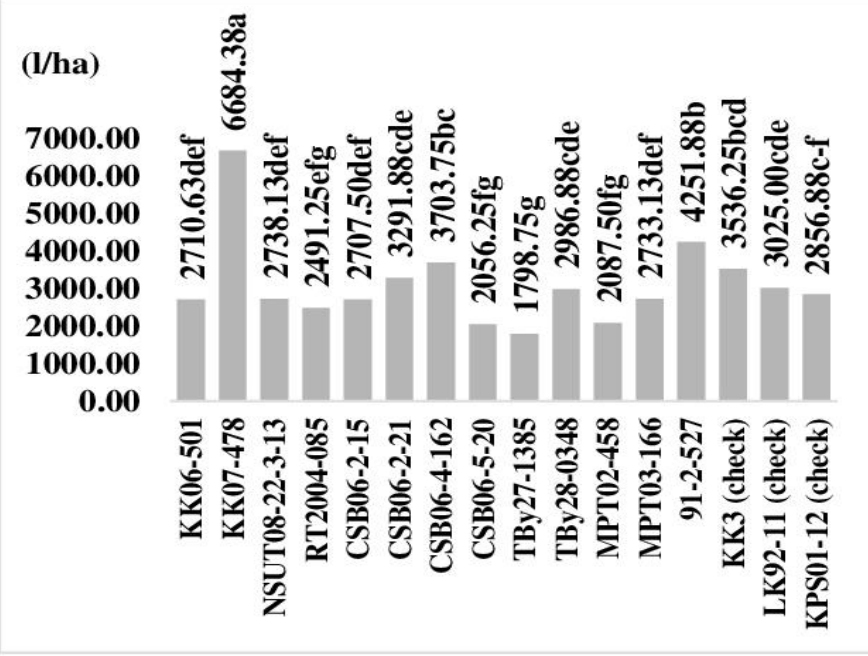

Fig.4 Means of estimated ethanol yield of 16 sugarcane varieties grown at location 1 (L1)

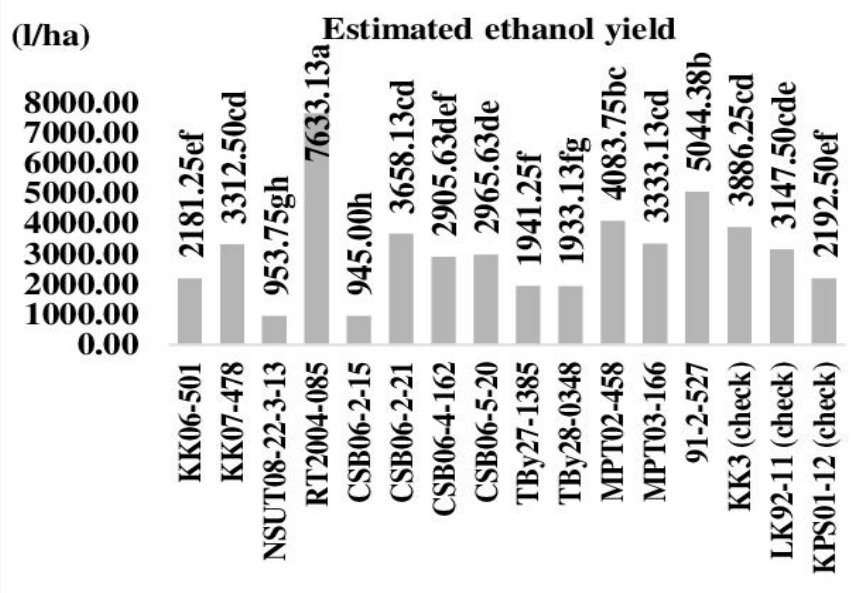

Fig. 6 Means of estimated ethanol yield of 16 sugarcane varieties grown at location 2 (L2) 
Table 5. Juice yield and related traits of sugarcane grown under rain-fed condition in location 2 (L2).

\begin{tabular}{|c|c|c|c|c|c|c|c|}
\hline Variety & $\begin{array}{l}\text { Juice yield } \\
\text { (I/ha) }\end{array}$ & $\begin{array}{l}\text { Juice weight } \\
\text { (t/ha) }\end{array}$ & SG & $\begin{array}{l}\text { Fiber } \\
(\%)\end{array}$ & Pol & $\begin{array}{l}\text { Purity } \\
\text { (\%) }\end{array}$ & $\begin{array}{l}\text { Percent } \\
\text { of ethanol }\end{array}$ \\
\hline KK06-501 & 18486.9def & 20.2def & 1.093 & 18.79ab & 14.12ab & $88.31 \mathrm{abc}$ & $11.79 b$ \\
\hline KK07-478 & 29923.2cde & $31.2 \mathrm{cde}$ & 1.042 & $18.22 \mathrm{abc}$ & 13.59ab & $86.78 \mathrm{bcd}$ & $11.06 \mathrm{~b}-\mathrm{e}$ \\
\hline NSUT08-22-3-13 & $8171.3 f$ & $8.7 f$ & 1.059 & $19.57 a$ & $14.74 a$ & $90.11 a b$ & $11.69 b c$ \\
\hline RT2004-085 & $57467.5 a$ & $67.6 a$ & 1.173 & $19.61 a$ & $14.72 a$ & $88.39 a b c$ & $13.26 a$ \\
\hline CSB06-2-15 & $8929.4 f$ & $9.5 f$ & 1.058 & $17.17 \mathrm{bcd}$ & $12.80 \mathrm{bc}$ & $85.99 c d$ & $10.60 c-g$ \\
\hline CSB06-2-21 & $36433.2 b c$ & $38.7 b c$ & 1.064 & $15.85 d$ & $11.06 \mathrm{~d}$ & $85.96 \mathrm{~cd}$ & $10.09 \mathrm{efg}$ \\
\hline CSB06-4-162 & 24235.6cde & $26.2 \mathrm{cde}$ & 1.075 & $19.52 a$ & $15.07 a$ & $89.85 a b$ & $11.84 b$ \\
\hline CSB06-5-20 & $31194.4 \mathrm{~cd}$ & $32.8 \mathrm{cde}$ & 1.053 & $15.66 \mathrm{~d}$ & $11.33 \mathrm{~cd}$ & $90.33 a$ & $9.51 \mathrm{~g}$ \\
\hline TBy27-1385 & 18988.8def & 20.5 def & 1.077 & $15.43 d$ & $11.05 d$ & $86.10 \mathrm{~cd}$ & $10.30 \mathrm{~d}-\mathrm{g}$ \\
\hline TBy28-0348 & 17298.1ef & 18.5ef & 1.066 & $18.34 a b c$ & 13.92ab & $88.48 a b c$ & 11.15b-e \\
\hline MPT02-458 & $36390.6 b c$ & $38.5 b c$ & 1.059 & $18.68 a b$ & 14.16ab & $89.15 a b c$ & $11.22 \mathrm{~b}-\mathrm{e}$ \\
\hline MPT03-166 & $34458.8 b c$ & $34.5 \mathrm{cbd}$ & 1.002 & $16.26 \mathrm{~d}$ & $12.00 \mathrm{~cd}$ & $80.91 \mathrm{e}$ & $9.71 \mathrm{fg}$ \\
\hline $91-2-527$ & $45433.8 \mathrm{ab}$ & $48.8 b$ & 1.074 & $16.79 \mathrm{~cd}$ & $11.92 \mathrm{~cd}$ & $84.73 d$ & $11.07 \mathrm{~b}-\mathrm{e}$ \\
\hline KK3 (check) & $35765.6 b c$ & $36.6 b c$ & 1.024 & $18.68 \mathrm{ab}$ & 14.00ab & $88.23 a-d$ & $10.88 b-f$ \\
\hline LK92-11 (check) & 27298.8cde & $30.3 \mathrm{cde}$ & 1.107 & $18.30 \mathrm{abc}$ & $13.82 \mathrm{ab}$ & $88.57 a b c$ & $11.54 \mathrm{bc}$ \\
\hline KPS01-12 (check) & 19293.1def & 20.7def & 1.071 & $19.02 a$ & $14.63 a$ & $90.76 a$ & $11.35 \mathrm{bcd}$ \\
\hline F-test & $* *$ & $* *$ & ns & $* *$ & $* *$ & $* *$ & $* *$ \\
\hline CV (\%) & 15.27 & 16.66 & 4.33 & 5.87 & 2.30 & 2.40 & 6.46 \\
\hline
\end{tabular}

related parameters on sugarcane (Khan et al., 2012) and on other ethanol producing crops like sweet sorghum (Bunphan et al., 2014). These studies did not go further into studying specifically the relationship between ethanol yield and its related traits as compared to our study where we focused most importantly on ethanol yield. In our report, the TSS had moderate correlation with Pol, this was also observed by Krishna and Kamat (2017) and Khan et al. (2012) who reported that these traits had highly positive correlation. A study by Khumla et al. (2012) found out that TSS had positive correlation to pol and purity, a small contrast to our study as we did not find any relationship between TSS and purity.

\section{Materials and methods}

The experiments were conducted at two locations under rainfed and paddy field conditions in Maha Sarakham province; the first location (location 1 or L1) is located at Huai Peung sub-district, Kut Rang district (sugarcane field) where is the upland and sugarcane production area, another field was located at Hua Rue sub-district, Wapi Prathum district (location 2 or L2; previously used as upland paddy rice field). Both experiments were conducted under rain-fed condition, that is no additional water was used for irrigation on both the fields as the whole growth was maintained by natural rainfall only.

The experiments were set up in a randomized complete block design (RCBD) with sixteen varieties made up of thirteen (13) elite lined developed by breeders around Thailand and three check varieties that have been used in sugarcane production for more than 10years in Thailand. The study was conducted in two locations as stated above. The sixteen (16) sugarcane lines were used as the treatments in this study and each treatment was replicated 3 times. The sixteen (16) varieties used in this research are varieties KK06-501, KK07-478, NSUT08-22-3-13, RT2004-085, CSB06-2-15, CSB06-2-21, CSB06-4-162, CSB06-5-20, TBy27-1385 TBy28-0348, MPT02458, MPT03-166, 91-2-527, KK3, LK92-11 and KPS01-12; with the last three varieties in the list being check varieties. The plots were made such that the consists of $4 * 6 \mathrm{~m}$ rows making a total plot size of $31.2 \mathrm{~m}^{2}$ (sugarcane field; L1) and $26 \mathrm{~m}^{2}$ (paddy rice field; $L 2$ ) because the length was reduced to $5 \mathrm{~m}$. The spacing was set at $1.30 \mathrm{~m}$ between rows and $0.50 \mathrm{~m}$ between the plants. The sixteen varieties were planted on the $9^{\text {th }}$ November 2016 and $17^{\text {th }}$ December 2016 in the rain-fed and paddy rice fields, respectively. A NPK (15-15-15) fertilizer was applied at a rate of $50 \mathrm{~kg} / \mathrm{rai}(312.5 \mathrm{~kg} / \mathrm{ha})$ at 2 and 6 months after planting, weeding was done by hand at 2 and 6 months after planting. Prior to planting, soil samples were collected from the $0-30 \mathrm{~cm}$ plough layer and taken to the lab to for soil analysis and the results are shown on Table 1.

\section{Data collection}

Because the primary focus of this research was on yield and yield attributes of sugarcane, therefore, data was recorded at 12-13 months after planting when the plants were mature. The sixteen sugarcane varieties were harvested on December $1^{\text {st }} 2017$ and January $3^{\text {rd }} 2018$ at sugarcane field and upland paddy rice field, respectively. Harvesting was strategically done so that samples for data collection were harvested in the middle two rows and the guard rows excluded to avoid any errors. The eight parameters recorded included; juice yield $\left(\mathrm{L} \mathrm{ha}^{-1}\right)$ was determined after squeezing juice from the stalk, juice weight (ton ha-1) was determined by digital scale, total soluble solid (TSS) was recorded by using hand refractometer (ATAGO N-1E, city, Japan, specific gravity (SG) was calculated by using formula $D=M / V$ when $M$ is juice weight and $V$ is juice volume or juice yield; percent of ethanol, pol, fiber, purity and ethanol yield was calculated as per Somani and Taylor (2003):

$\frac{\text { L ethanol }}{\text { ha }}=\frac{(\text { Brix }-3) \mathrm{kg} \mathrm{suc}}{100 \mathrm{~kg} \text { juice }} \times \frac{\text { SG kg juice }}{\mathrm{L} \text { juice }} \times \frac{\mathrm{L} \mathrm{juice}}{\mathrm{ha}} \times \frac{0.59 \mathrm{~L} \text { ethanol }}{\mathrm{kg} \mathrm{suc}}$

\section{Data analysis}

Data collected was subjected to the Analysis of variance (ANOVA) using STATISTICS 9 computer software package and treatment means were separated using least significant difference (LSD) at $5 \%$ probability level. A $G \times E$ analysis was 


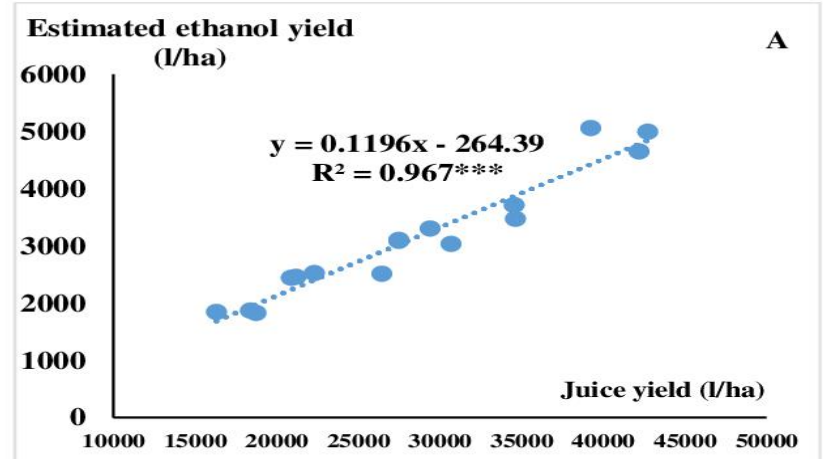

Estimated ethanol yield (1/ha)
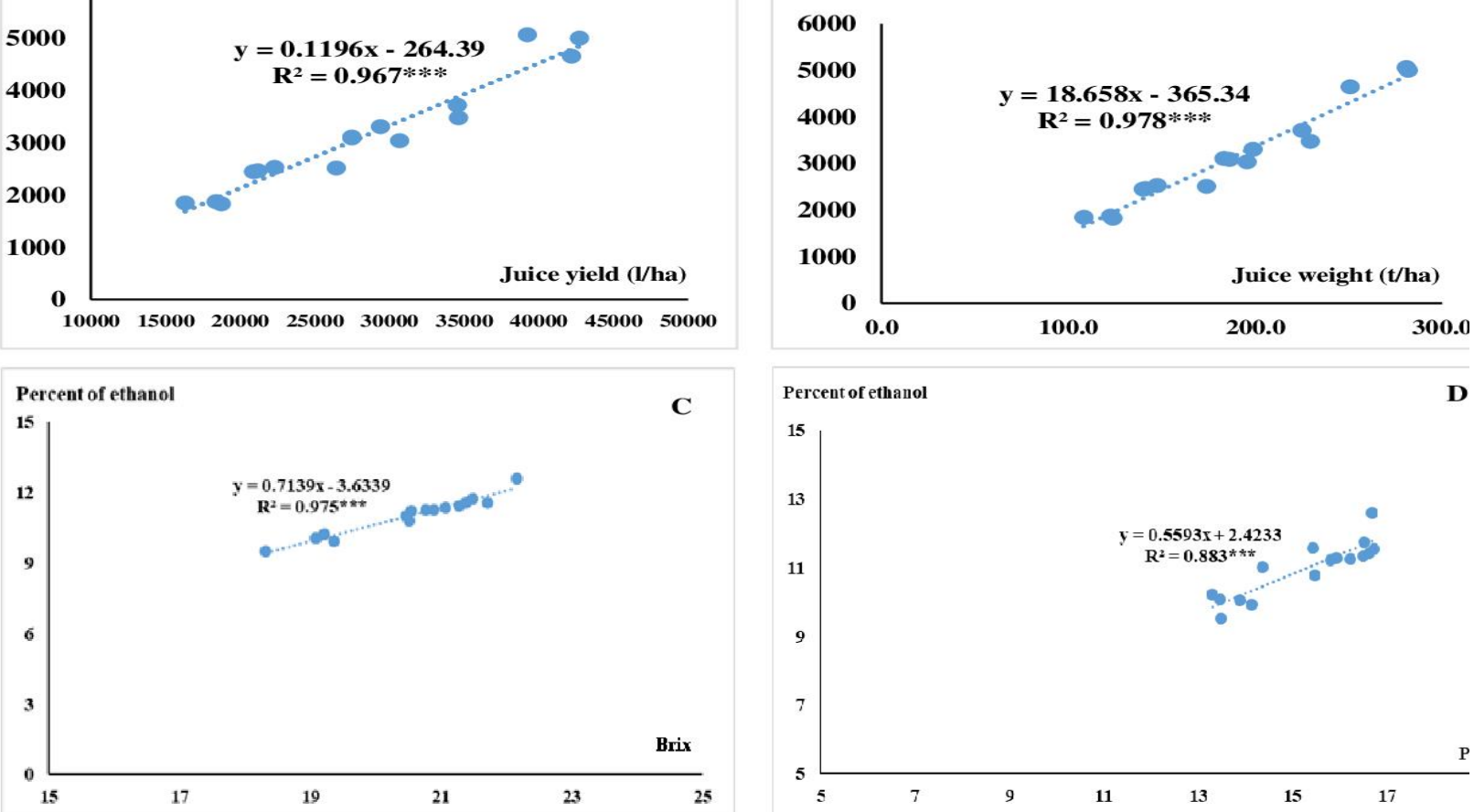

Percent of ethanto
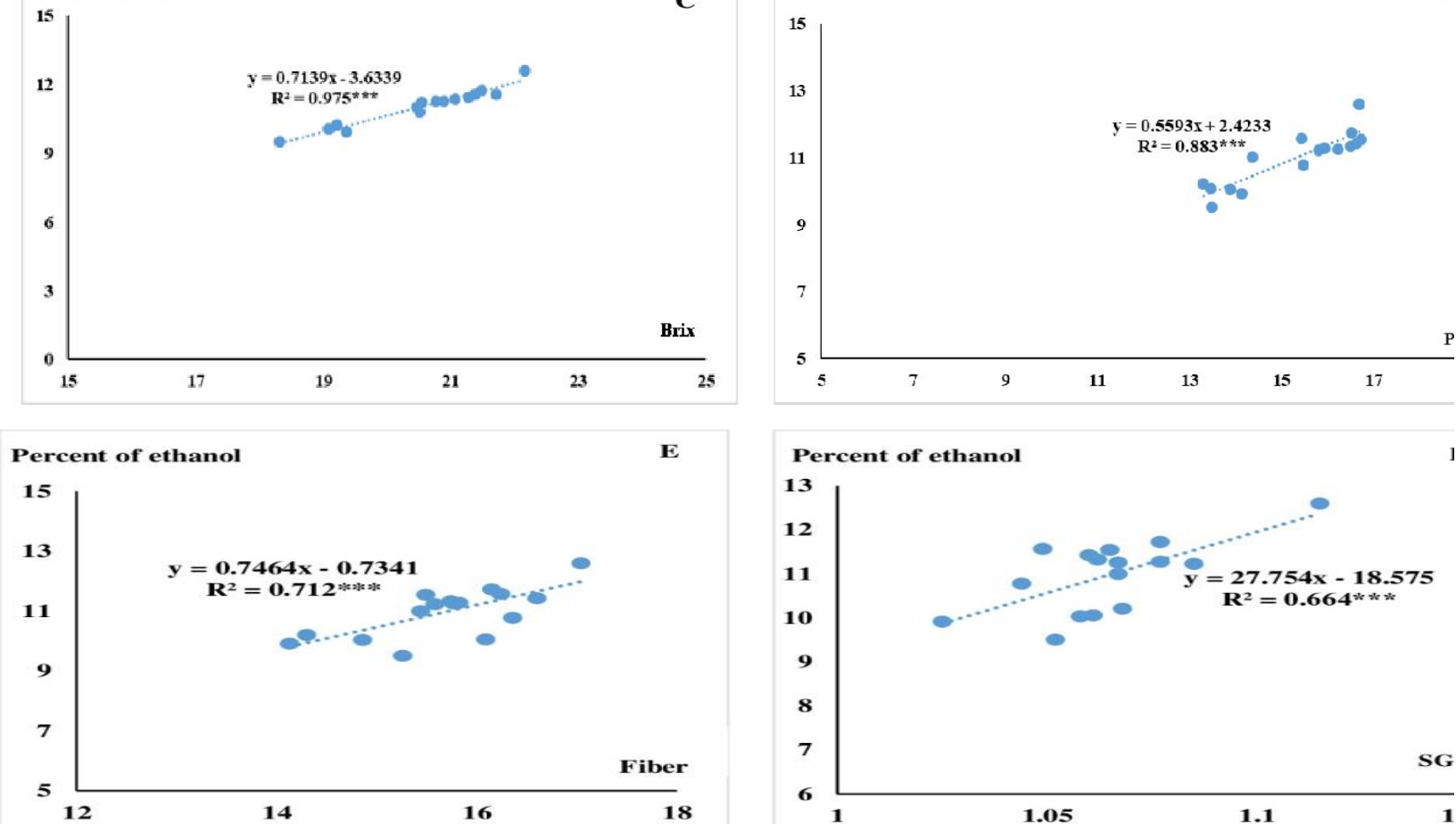

Percent of ethanol
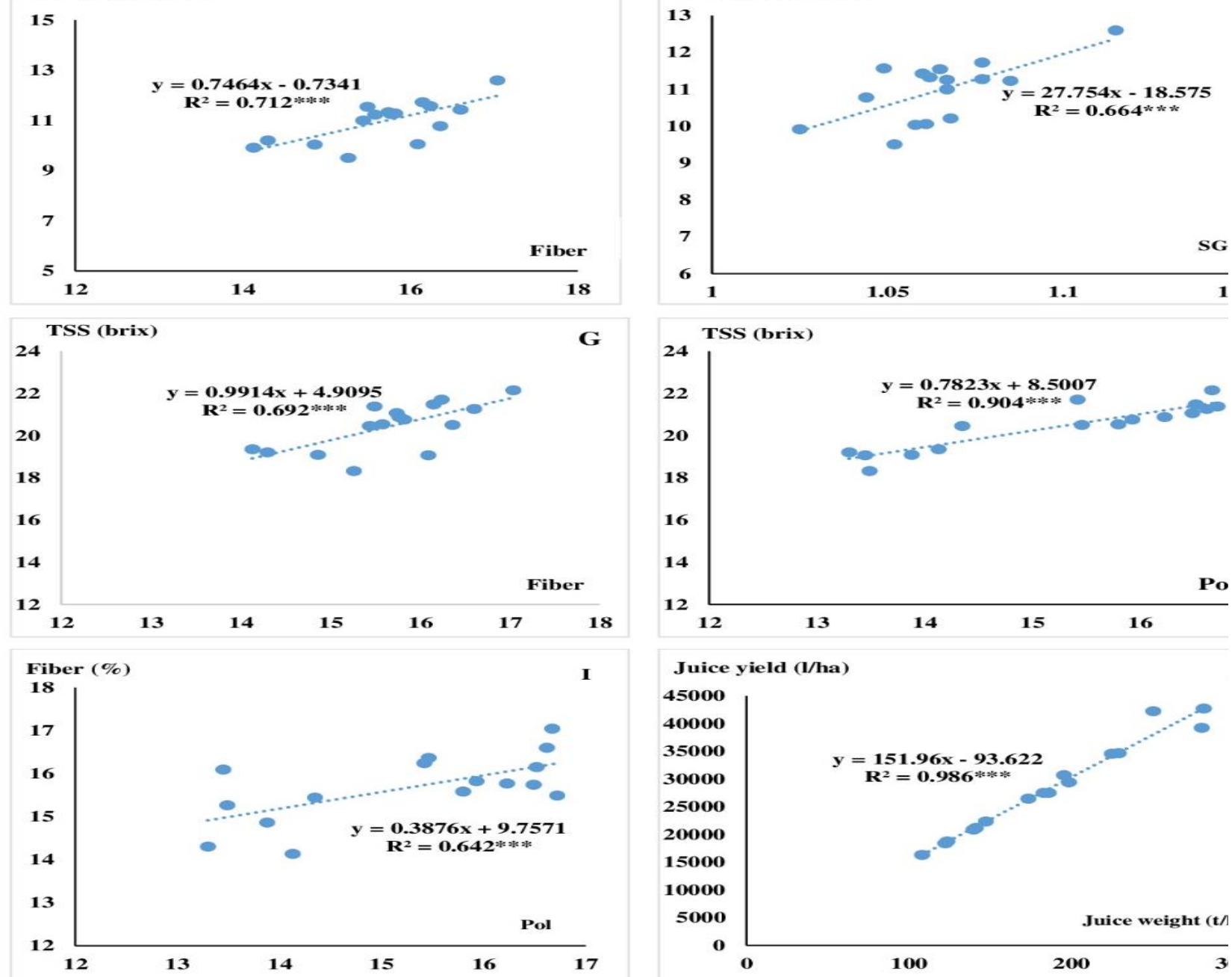

Fig 7. Regression analysis between the ethanol yield related traits of 16 sugarcane varieties at two study locations grown under rainfed condition. 
also performed on the results to determine the interaction between location and the varieties. A correlation analysis was done to determine the relationship between the cane and ethanol yield with the other agronomic traits.

\section{Conclusions}

Our study showed that the varieties under evaluation were not affected by location and thus can be thought to be stable across location but a further study on more locations will be ideal. Correlation analysis in our study showed that to improve the ethanol yield of sugarcane it is important to first improve the yield related traits like cane yield, juice yield and TSS. Two varieties KK07-478 and RT2004-085 showed to perform better than others in respect to the ethanol yield related parameters like high cane and juice yield therefore can be studied further before being released to farmers.

\section{Acknowledgments}

This research project was financially supported by Mahasarakham University (Fast Track 2020), National Science and Technology Development Agency (NSTDA) and Thai Sugar Millers Cooperation Limited (TSMC). We would like to thank the Department of Agricultural Technology, Faculty of Technology Mahasarakham University and 4th year undergraduate students of Department of Agricultural Technology Mahasarakham University.

\section{References}

Alamri SA, Hashem M, Alrumman SA and Al-Qahtani MSA (2015) Enhancement of bio-ethanol production from date molasses by non-conventional yeasts. Res J Microbiol. 10: 114-125.

Arshad M, Hussian T, Iqbal M and Abbas M (2017) Enhanced ethanol production at commercial scale from molasses using high gravity technology by mutant $S$. cerevisiae. Braz J Microbiol. 48 (3): 403-409.

Bella LP, di Stringer JK, Wood AW, Royle AR and Holzberger GP (2009). What impact does time of harvest have on sugarcane crops in the Herbert River district? Proc Aust Soc Sugar Cane Technol. 31:337-348.

Bonnet GD, Hewitt ML and Glassop D (2006) Effects of high temperatures on growth and composition of sugarcane internodes. Aust J Agric Res. 57:1087-1095.

Bunphan D, Prasit J and Jirawat S (2014) Genetic variation and correlation of some agronomic traits, biomass and ethanol yield in diverse sweet sorghum (Sorghum bicolor L. Moench) cultivars. Khon Agri J. 42 (4):605-616.

Bunphan D, Prasit J, Jirawat S, Joseph EK and William FA (2015) Estimation methods and parameter assessment for ethanol yields from total soluble solids of sweet sorghum. Ind Crops Prod. 63:349-356.

Carvallo JLN, Nogueirol RC, Menandro LMS, Bordal RO, Borges CD, Cantarella H and Franco HCJ (2015) Agronomic and environmental implications of sugarcane straw removal: a major review. Glob Change Biol Bioenergy 9(7):1181-1195.

Choudray HR, Singh RK, Prajapat K and Choudhary GL (2013) Water management in Sugarcane.

National seminar on enhancing water productivity in Agriculture, March 8-9 Department of Agronomy. Banaras Hindu Univervisity, Varanasi-221005.Riajaya PD 2020 IOP Conf. Ser.: Earth Environ Sci. 418012058.
Ftwi M, Mekbib F and Abraha E (2018) Genotype x environment interaction and genotype evaluation for yield, yield components and qualities of sugarcane (Saccarum Spp.). Ethiopia Sci J Crop Sci. 7(1):249-264.

International Sugar Organization (2020) About sugar. Available source:

https://www.isosugar.org/sugarsector/sugar, 20 January 2021.

Jamoza JE, Owuoche J, Kiplagat O (2019) Estimates of genetic parameters and genotype by environment interactions for sugar yield and its components in sugarcane genotypes in Western Kenya. J Plant Breed Crop Sci.11(9):206-212.

Giri R, Kundu BS, Diwan P, Raj K and Wati L (2013) Ethanol production from direct sugarcane and juice by yeast. Agric Sci Digest. 33 (3):188-192.

Guilly S, Dumont T, Thong-Chane A, Barau L and Hoarau JY (2017) Analysis of multi environment trials (MET) in the sugarcane breeding program of Reunion Island. Euphytica. 213:1-20.

Karim SMR, Pal SK, Afrad MSI, Rahman MH and Miah MNA (2016) Problems faced by farmers in sugarcane cultivation under Joypurhat sugar mills. Bangladesh J Sugarcane. 37:76-82.

Khan IA, Sajida B, Shafqat Y, Abdullah K, Nighat S and Shafique AA (2012) Correlation studies of agronomic traits for higher sugar yield in sugarcane. Pak J Bot. 44 (3):969-971.

Khan MGM, Naidu PN and Jokhan AD (2015) Stability analysis in elite sugarcane varieties of Fiji. IEEE Proceedings of 2015, 2nd Asia-pacific world congress on computer science and engineering (APWC on CSE) DOI: 10.1109/APWCCSE.2015.7476239.

Khumla N, Thumthong P, Lertprasertrat K, Chuekittisak R, Jattupornpong S, Kongtian S and Suknimit M (2012) Evaluation of the Promising Sugarcane Clones under Rainfed Conditions. Khon Agr J. 4 (3):37-44.

Knox JW, Rodrıguez D'iaz JA, Nixon DJ and Mkhwanazi M (2010). A preliminary assessment of climate change impacts on sugarcane in Swaziland. Agric Syst. 103(2):6372.

Krishna B and Dharm NK (2017). Character association among cane yield and their component traits in sugarcane under waterlogged condition. Int J Curr Microbiol Appl Sci. 6(10): 2331-2339.

Kumar D, Kumar S, Meena LK, Meena LR, Singh SP (2018). Stability analysis of sugarcane (Saccarum $\mathrm{spp}$ ) genotypes for matric and quality traits by AMMI model. Indian J Agric Sci. 88(4):657-664.

Lavarack BP (2003) Estimates of ethanol production from sugar cane feedstock. Proceedings of the Australian Society of Sugar Cane Technology. 25:1-9.

Lenka R and Luboš S (2013) Global sugar market - the analysis of factors influencing supply and demand. Acta Univ Agric et Silvic Mendelianae Brun. 61(2):463-471.

Li YR and Wei YA (2006) Sugar industry in China: R \& D and policy initiatives to meet sugar and biofuel demand of future. Sugar Tech. 8(4):203-216.

Li YR and Yang LT (2014) Chinese sugarcane and sugar industry in recent 10 years, In Proceedings of the 5th International Association of Professionals in Sugar and Integrated Technologies: Green Technologies for Sustainable Growth of Sugar \& Integrated Industries in Developing Countries, Y.-R. Li, G. P. Rao, S. Solomonetal.,Eds., pp.1-10. 
Mattos de PHC, de Oliveira RA, Bespalhok F, João C, Daros E and Veríssimo MAA (2013) Evaluation of sugarcane genotypes and production environments in Paraná by GGE biplot and AMMI analysis. Crop Breed Appl Biotechnol. 13(1):83-90.

McEnroe P and Coulter B (1964). Effect of Soil pH on Sugar Content and Yield of Sugar Beet. Irish J. Agric. Food Res. 3(1):63-69.

McMillan JD (1997) Bioethanol production: Status and prospects. Renew Energ. 10: 295-302.

Mohsen KE, Zingsheim O, El-Shourbagy MN, Moore PH and Komor E (1998) Growth and sugar storage in sugarcane grown at temperatures below and above optimum. J Plant Physiol. 153 (5-6):593-602.

Momotarz A, Davidson WR, Zhao D, McCord PH, Sandhu HS, Baltazar M, Islam MdS and Arbelo C (2020) Genotype-byenvironment interaction analysis across three crop cycles in sugarcane. J Crop Improv. Doi: 10.1080/15427528.2020.1817220.

Péné CB and Béhou YM (2020) Genotype x Environment Interactions in Sugarcane under Irrigation for Agronomic Traits at Advanced Screening Stage in Ferké, Northern Ivory Coast. J Exp Agric Int. 42(2):97-115.

Purseglove JW (1974) Tropical Crops. Monocotyledons. The English Language Book Society and Longman, London.

Rea R and Vieira O dS (2002) Genotype x environment interactions in sugarcane yield trials in the central- western region of Venezuela. Interciencia. 27:11.

Raijaya PD (2020) Rainy season period and climate classification in sugarcane plantation regions in indonesia. IOP Conf. Series: Earth and Environmental Science. 418: 012058. doi:10.1088/1755-1315/418/1/01205.
Rodríguez R, Bernal N, Jorge H, Garcia H and Puchades Y (2010) Genotype by environment interaction for yield in Sugarcane performance trials: A comparison of frequently used models. Proc Int Soc Sugar Cane Technol. 27:1-6.

Santchurn D, Ramdoyal K, Badaloo MGH and Labuschagne MT (2014) From sugar industry to cane industry: Evaluation and simultaneous selection of different types of high biomass canes. Biomass \& Bioenergy. 61:82-92.

Sapkota S, Gairhe S, Upadhyay N and Acharya Y (2017) Problems and opportunities in sugarcane production and marketing in Nepal. In Proceedings of $30^{\text {th }}$ National Winter Crops Workshop. Rampur, Chitwan: National Maize Research Program.

Somani RB and Taylor JRN (2003) Sorghum: a potential source of raw material for agro-industries. In Alternative Uses of Sorghum and Pearl Millet in Asia. Proceedings of the Expert Meeting, ICRISAT, Patancheru, Andhra Pradesh, India, 1-4 July Common Fund for Commodities. CFC Technical Paper No. 34. p 146-168.

Srivastava AK and Rai MK (2012) Review: Sugarcane production: impact of climate change and its mitigation. Biodiversitas. 13(4):214-227.

Waclawovsky AJ, Sato PM, Lembke CG, Moore PH and Souza GM (2010) Sugarcane for bioenergy production: an assessment of yield and regulation of sucrose content. Plant Biotechnol J. 8:263-276.

Zhao D and Li Y (2015) Climate change and sugarcane production: potential impact and mitigation strategies. Int J Agron. 2:1-10.

Zulu SM, Sibanda M, Tlali B (2019) Factors affecting sugarcane production by small-scale growers in Ndwedwe Local Unicipality, South Africa. Agriculture. 9(8):170. 